\title{
Correction to: The Struggle for Redress
}

\section{Correction to:}

J. Barton-Hronešová, The Struggle for Redress, Memory Politics and Transitional Justice, https://doi.org/10.1007/978-3-030-51622-2

One of the misspelt authors' name "Haris Siljadžić" has been corrected to "Haris Silajdžić" in pages 95, 101, 102, 106, 151, 204, 220, 263 and 269 of the book.

The updated versions of these chapters can be found at https://doi.org/10.1007/978-3-030-51622-2_3 https://doi.org/10.1007/978-3-030-51622-2_4 https://doi.org/10.1007/978-3-030-51622-2_5 https://doi.org/10.1007/978-3-030-51622-2_6

(C) The Author(s) 2021

J. Barton-Hronešová, The Struggle for Redress, Memory Politics and Transitional Justice, https://doi.org/10.1007/978-3-030-51622-2_8 